\title{
PADRÕES DE MOBILIDADE E MISCIGENAÇÃO RACIAL NO BRASIL ESCRAVISTA, RIO DE JANEIRO, SÉCULO XIX
}

\author{
PATTERNS OF MOBILITY AND RACIAL \\ MISCEGENATION IN SLAVEHOLDING BRAZIL, \\ 19TH CENTURY, RIO DE JANEIRO
}

\author{
Manolo Florentino \\ Universidade Federal do Rio de Janeiro, Rio de Janeiro, Brasil, <mgflorentino@gmail.com> \\ José Roberto Pinto de Góes \\ Universidade do Estado do Rio de Janeiro, Rio de Janeiro, Brasil, <joserobertogoes@gmail.com>
}

Resumo. O estudo tem por base empírica cartas de alforrias e registros de batismos de escravos do Rio de Janeiro no século XIX. Seu argumento central, igualmente observado por Joaquim Nabuco, diplomata e abolicionista brasileiro, é o de que a escravidão na América portuguesa apresentava grande singularidade em relação aos sistemas escravistas de outras regiões americanas. Em especial, os altos graus de alforrias, que além de ensejar uma acentuada miscigenação racial, permitia a mulatos e negros o acesso ao mercado de escravos, conferindo à ordem escravocrata níveis de adesão que ultrapassavam as fronteiras da cor.

Palavras chave: escravidão; mobilidade social; miscigenação racial.

Abstract. This study analyzes manumission papers and baptismal records of slaves in nineteenth-century Rio de Janeiro. It argues that slavery in Luso-America was remarkably distinctive from other slave systems in the Americas due to, among other factors, its high manumission rates. They not only encouraged substantial racial miscegenation, but also granted Mulattoes and Blacks access to the slave market, ensuring that participation into the slaveholding order reached out beyond the limits of skin color.

Key words: slavery; social mobility; racial miscegenation.

Fecha de recepción: diciembre de 2012. Fecha de aceptación: febrero de 2013.

Am. Lat. Hist. Econ., año 20, núm. 3, septiembre-diciembre, 2013, pp. 5-27 


\section{INTRODUÇÃO}

$\mathrm{E}$ "passou-se então para a outra banda do rio Diogo Dias, que fora almoxarife de Sacavém, o qual é homem gracioso e de prazer. E levou consigo um gaiteiro nosso com sua gaita. E meteu-se a dançar com eles, tomando-os pelas mãos; e eles folgavam e riam e andavam com ele muito bem ao som da gaita". Não há erro em dizer que o Brasil teve origem ali, na praia, à vista de Pero Vaz de Caminha, em meio à confraternização alegre do ex-almoxarife de Sacavém com os índios. Mas o que determinou a variedade racial e cultural brasileira foi o tipo de exploração do trabalho humano escolhido para consolidar a presença portuguesa no novo continente. A necessidade de escravos (ou o desejo de obtê-los) foi o que reuniu, nesta parte da América, povos tão diferentes como podiam ser cristãos medievais, em versão lusitana, primitivos aborígines americanos e o variado mosaico africano. A diversidade cultural brasileira é obra da escravidão; de sua consecução e continuidade, por mais de três séculos, e da alternativa encontrada quando não foi mais possível adiar o fim do tráfico transatlântico, a imigração de trabalhadores livres europeus.

A colonização moderna também ensejou sociedades escravistas, baseadas no tráfico de africanos, em outras regiões da América, como nas Antilhas e no Sul dos Estados Unidos. Cinco séculos depois, contudo, o panorama das relações raciais e culturais no Brasil apresenta traços peculiares, sobretudo quando comparado aos Estados Unidos, onde negros e brancos dificilmente dançam ao som da mesma gaita.

Já se argumentou que a diferença vem de longe, dos tempos coloniais. A colonização moderna haveria originado diferentes sociedades escravistas, cada qual fortemente marcada pela história e instituições sociais do colonizador. No caso do Brasil, a experiência lusitana na utilização do trabalho escravo teria ensejado uma legislação, influenciada pela Igreja católica e pela coroa, que protegiam em alguma medida a pessoa do escravo. Já no caso da colonização anglo-saxã, faltava tradição, legislação e igreja que atenuassem os rigores do cativeiro. Além disso, o desenvolvimento do capitalismo norte-americano teria levado a um tratamento mais severo conferido aos escravos, nas plantations. ${ }^{2}$

O problema imediatamente suscitado pela primeira perspectiva é que, se é admissível uma escravidão mais cruel, também o é uma escravidão mais moderada, quiçá branda. Mas moderada para quem, cara-pálida?, é o caso de se perguntar. Não há como medir a crueldade da escravidão, pois não é possível medir a própria crueldade, desencarnada dos homens,

\footnotetext{
${ }^{1}$ Caminha, "Carta", 1992, p. 88.

2 Klein, "Experiência”, 2012; ver também Tannembaum, Negro, 1968.
} 
alheia a histórias, humores e estados humanos. A escravidão no continente americano foi democraticamente cruel, ser escravo no Brasil era um destino não procurado, ingrato, de pobreza, dificuldade e humilhação. No Sul dos Estados Unidos e nas Antilhas era a mesma coisa. Mas há motivos para crer que a diferença vem de longe. Quando se deram as abolições, o nível de integração dos mulatos -e mesmo dos negros- no mundo dos homens livres já era muito maior no Brasil do que no Sul dos Estados Unidos, onde eram muito poucos os "homens de cor" na população livre.

Já em 1779, nas freguesias urbanas e rurais do Rio de Janeiro, onde a plantation açucareira tinha grande peso na economia regional, os "homens de cor" representavam 31\% de todos os livres. Em Campos dos Goitacazes, a população parda e negra, livre, era mais de $1 / 3$ do total. ${ }^{3}$ Na província que detinha a maior quantidade de escravos durante a década de 1830 -Minas Gerais-, os mestiços representavam 2/3 dos homens livres. ${ }^{4}$ Este perfil aumentou ao longo do século XIX, de tal maneira que o Censo de 1872 indica que metade da população livre de todo o Brasil era constituída por negros e pardos. ${ }^{5}$

Negros e mulatos, pessoas livres e proprietárias. Em Minas Gerais, na localidade de Serro Frio, em 1738, quase 1/4 dos proprietários eram forros; possuíam 10\% dos escravos. Em 1771, o mesmo ocorria em Congonhas de Sabará. ${ }^{6}$ Em algumas localidades baianas de finais do século XVIII, os negros e mulatos livres representavam entre $20 \%$ e a metade dos proprietários. Em 1835, em áreas dominadas pela cultura do fumo, os "não brancos" podiam corresponder a 1/3 dos donos de escravos, proporção que se elevava a quase metade em algumas regiões dedicadas à plantação de cana. ${ }^{7}$

\section{As ALFORRIAS no Rio DE JANEIRO, 1840-1850}

As cartas de alforria revelam o momento crucial da travessia ao mundo dos livres. Os resultados apresentados a seguir referem-se a uma série de

${ }^{3}$ Faria, Colônia, 1998, p. 128.

"Paiva, "População", 1996, passim.

5 Recenseamento, 1974?

${ }^{6}$ Luna e Costa, Minas, 1982, p. 45. Em certas partes do Vale do Paraíba paulista, onde o açúcar foi paulatinamente cedendo lugar ao café, em 1797-1798 os negros e pardos livres constituíam de $0.2 \%$ a $9.8 \%$ dos proprietários; trinta anos depois eram de $2.1 \%$ a $14.3 \%$. Durante o mesmo período, na região de Santos e São Sebastião, ligada ao açúcar e ao grande comércio, os homens de cor correspondiam de $10 \%$ a 1/4 dos proprietários, cifras que, em áreas mineradoras paulistas, passaram de 28\%, em 1798, para 41\% vinte e cinco anos depois, em Costa, Arraia-miúda, 1992, pp. 53-55.

${ }^{7}$ Barickman, "Cores", 1999. 
5516 cartas, pertencentes ao acervo do Arquivo Nacional, escritas entre os anos de 1840 e 1850 .

Estudos sobre o assunto têm indicado que as mulheres escravas, sobretudo as nascidas no Brasil, tinham mais chances de obter uma carta de alforria. ${ }^{8}$ Também nas cartas do Rio de Janeiro, naquela década de 1840, eram elas as mais privilegiadas (cerca de 60\% do conjunto de libertos) (ver tabela 1). Em todas as grandes faixas etárias as mulheres predominavam (ver gráfico 1). No entanto, não eram majoritariamente crioulas: as africanas eram pouco mais da metade. Aliás, a população africana de ambos os sexos parece ter sido tão bem aquinhoada com cartas de alforrias quanto os crioulos -eram africanos 56\% dos alforriados. Este número é um pouco abaixo do percentual de africanos na população escrava global do Rio, na década precedente, que era de $59 \% .{ }^{9}$ Assim, se os crioulos costumavam ter maior acesso ao mundo dos homens livres, a vantagem era pequena, no Rio, àquela época.

A maior parte das cartas não traz a idade do beneficiado. Mas as que a indicam, revelam o quanto eram ciosos e prudentes os senhores, na concessão de alforrias a suas propriedades: somados, crianças e velhos, sobretudo as primeiras, eram os mais agraciados.

Quatro em cada dez cartas alforriavam meninos e meninas de até dez anos de idade. Eram quase todos crioulos, evidentemente. A maior parte dos crioulos libertados, aliás, não possuía mais do que dez anos (59\%), enquanto quase metade dos africanos tinha mais de 40 anos (47\%). Não surpreende que raras crianças africanas se beneficiassem de alforrias, pois poucas delas havia. Mas permanece o contraste entre as duas "nações": apenas aproximados 5\% dos crioulos libertos tinham mais de 40 anos. Considerando que a velhice chegava antes desta idade para os escravos, pode-se dizer que os africanos levavam quase a vida toda para obter uma carta de alforria, enquanto os crioulos libertos eram livres desde cedo. Henry Koster preferia ter que se fazer obedecer por escravos africanos, ao invés de crioulos. Dizia que um africano já habituado ao Brasil era mais leal do que aqueles, sempre muito impacientes, por verem tantos iguais a eles libertos ou livres. ${ }^{10}$ Faz sentido, à luz dessas cartas de alforria. $\mathrm{O}$ africano precisava ser leal até o fim. Já no caso dos crioulos, sempre podia ter sido diferente (ver tabela 2).

Quase todas as crianças com cor assinalada eram pardas, com exceção de duas, em 89 casos: a "preta" Maria dos Ramos, baiana de nove anos, e Esperança "negrinha", de cinco (filha de Rita e Felipe, que a resgatou

\footnotetext{
${ }^{8}$ Mattoso, "Carta", 1976.

${ }^{9}$ Inventários post-mortem, 1810-1830, em Arquivo Nacional, Rio de Janeiro (em diante ANRJ).

${ }^{10}$ Koster, Viagens, 1978, pp. 400-401.
} 


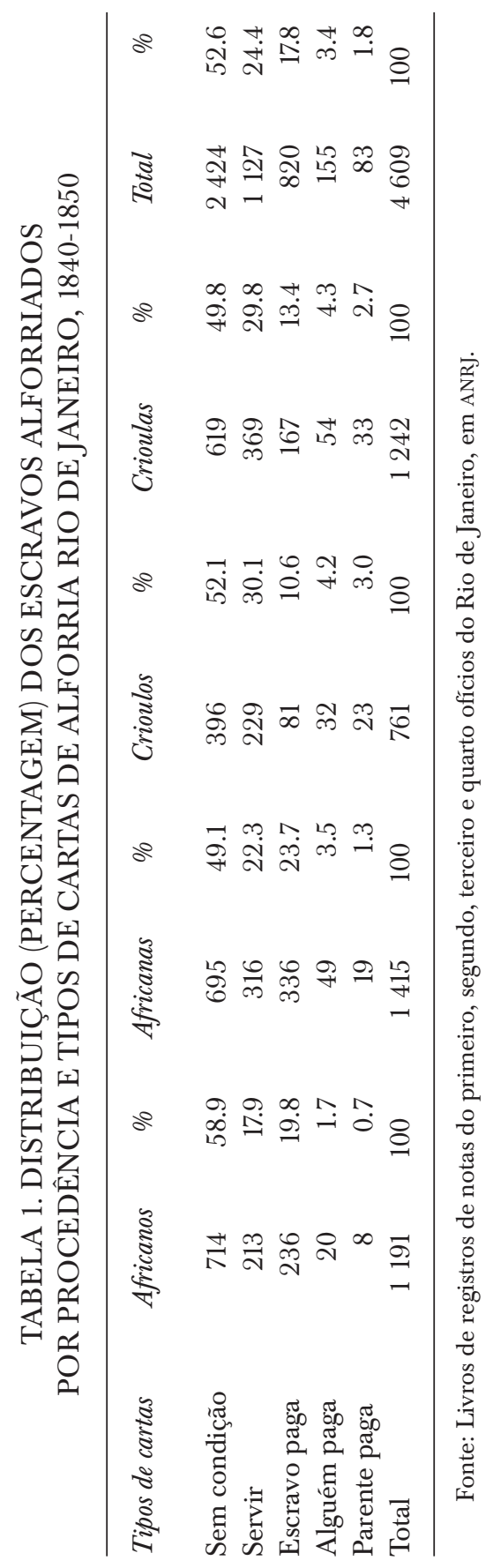




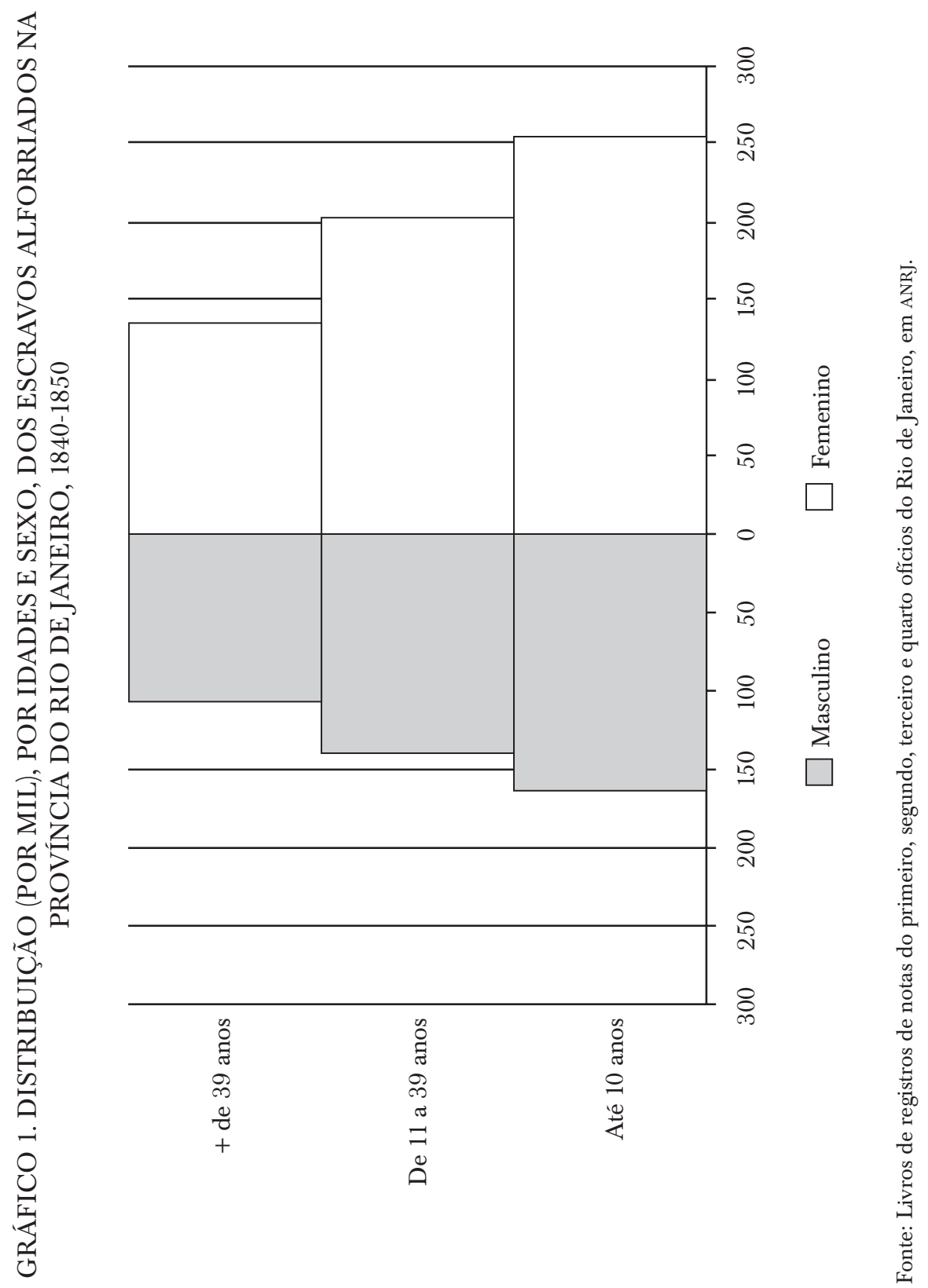




\begin{tabular}{|c|c|c|c|}
\hline 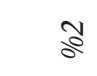 & 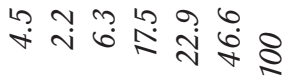 & 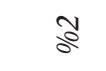 & $\begin{array}{ll}0 \\
0\end{array}$ \\
\hline बढ & $\&: \& \& \&:$ & 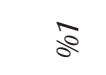 & 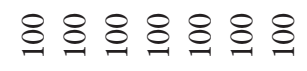 \\
\hline$\widetilde{\Xi}$ & ㅁ & కี & 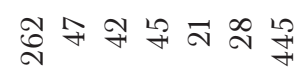 \\
\hline$\therefore$ & 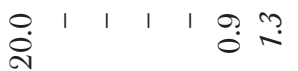 & $\therefore$ & 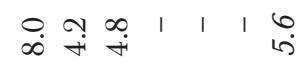 \\
\hline 害 & $\infty 11|1|-\infty$ & 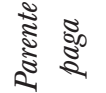 & 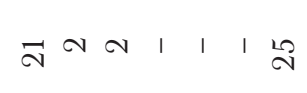 \\
\hline$\therefore$ & 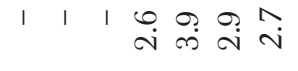 & $\therefore$ & 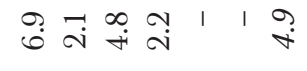 \\
\hline 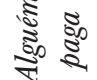 & $1 \mid 1-\infty \infty 0$ & 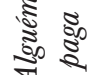 & $\stackrel{\infty}{\sim}-\infty-1$ I \\
\hline$\therefore$ & 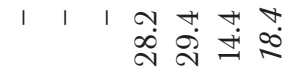 & $\therefore$ & 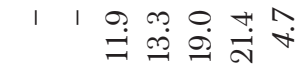 \\
\hline 蜜急 & $111=2$ & 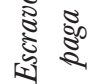 & 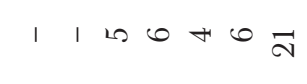 \\
\hline$\therefore$ & 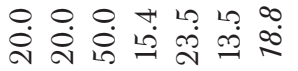 & $\therefore$ & 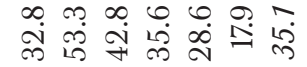 \\
\hline 密 & 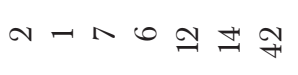 & 密 & 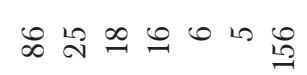 \\
\hline & 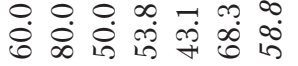 & $\therefore$ & 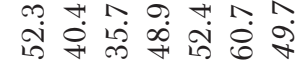 \\
\hline 胥 & ৩ナরন্রেন & 急 & 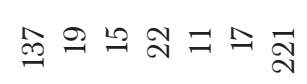 \\
\hline 竎 & 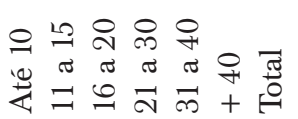 & 气ूँ & 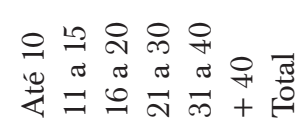 \\
\hline
\end{tabular}


pela quantia de 300000 réis, em 1849). Ao menos 16 mães destas crianças mulatas eram africanas, como Joana Monjolo, Rita Moçambique, Angélica Rebola, Benedita Inhambane e outras. As mães assinaladamente crioulas eram 25, sendo sete delas descritas como "pardas". O fato das africanas serem quatro em cada dez mães de filhos mulatos é sinal inequívoco do processo de miscigenação racial. O nome do pai, a fonte jamais o fornece.

Os motivos pelos quais o senhor, ou a senhora, concediam a alforria, no caso das crianças, eram eloqüentes assim: submissão, amizade, amor, amor de cria, criado como filho, pelo amor que lhe tem, por amor e afeição, por ter amor e tratarmos como filho, por estar criando, por ter criado em meus braços e consagrar amizade como se fosse uma própria mãe. $\mathrm{O}$ motivo por trás dos motivos, na verdade, eram os bons laços que uniam os pais dessas crianças aos senhores. Isto lembra bastante a família ampliada de Gilberto Freyre, da qual alguns escravos eram parte integrante. $\mathrm{O}$ exemplo limite desta era a de Tomás de Almeida, que fez constar numa carta que, "por fragilidade humana", tivera três filhos com Antônia Conga, sua escrava. E por "amor filial e dever da natureza", alforriou Libânia, de dois anos, Gertrudes, de quatro, e Deolinda, de quinze, além da mãe, Antônia. Ele era, literalmente, pai de seus escravos.

Já tivemos oportunidade de estudar algo acerca de crianças escravas como estas, objetos do amor filial e senhorial juntos. ${ }^{11}$ Maria Graham escreveu que elas passavam a infância "a comer, beber, e correr por aqui e ali, nos termos da igualdade familiar", ${ }^{12}$ mas Machado de Assis contou uma outra história, quando fez de uma criança escrava uma personagem, o Prudêncio, do romance Memórias póstumas de Brás Cubas. Ele tinha a afeição do amo, que, ao morrer, o libertou; mas era igualmente o alvo do sadismo do iô-iô, Brás Cubas, que o montava e lhe dava bofetadas.

De todo modo, tanto amor filial não significava sempre a liberdade imediata. Em quase $1 / 3$ dos casos, as crianças ficavam obrigadas a servir mais um bocado. Por mais dez, vinte anos, ou, mais freqüentemente ainda, pelo tempo que restasse de vida aos amos. Com a menina Laura, de sete anos, parda, pertencente a Ana Joaquina de Miranda, aconteceu coisa pouco diferente. A carta de alforria dela estipulava que deveria servir ainda por mais dez anos à madre Maria Theodora de Noronha, do Convento Nossa Senhora da Ajuda. Fora dada de presente à serva de Deus. A liberdade das crianças também era vendida, embora não fosse o mais freqüente. A escrava Eufrosina, mãe de Marcelino, de apenas um ano e meio de idade, recebeu uma esmola e, por 32000 réis, comprou a liberdade do filho.

\footnotetext{
${ }^{11}$ Florentino e Góes, "Crianças”, 1999.

${ }^{12}$ Graham, Diário, 1990, p. 346. Graham esteve no Brasil entre 1821 e 1823.
} 
Na idade adulta, após os 16 anos, podia acontecer de o escravo comprar a sua própria liberdade. Na faixa etária compreendida entre 16 e 20 anos, $10 \%$ das cartas são desse tipo. Entre 20 e 30 anos, 21\%; e, entre 30 e 40, auge e final da vida adulta, o cume: $26 \%$. Apenas $17 \%$ das cartas dos mais velhos, de mais de 40 anos, eram desse tipo. Mas a maior parte das alforrias da população adulta é a mescla de cartas incondicionais ou que obrigavam a servir um pouco mais.

Os motivos assinalados eram sempre os bons serviços prestados. Ao menos duas cartas dizem a duração dos serviços. Generosa, uma mulata, de 27 anos, servia há quinze anos -portanto, desde os doze. Ou fora comprada nesta idade (é possível, já que era mineira), ou o senhor dela entendia que, a partir daquela idade, passara a servir de fato, como escrava, e não como criança. A outra carta é de João Cabinda, de 30 anos, que servia há dezesseis, em 1841. Fora comprado aos catorze anos, em 1825. Naquela época, pois, os navios desembarcavam garotos de catorze anos no porto do Rio. João por Cristo e Cabinda por Nação pagou 400000 réis pela carta -de posse dela, que destino terá levado? Ao lado do genérico "bons serviços", um caso de "idade avançada" (Teresa Angola, 40 anos) e outro insinuoso, o de Sabrina Rebolo, 20 anos redondos, descrita como "mocamba perfeita" -estava avaliada em 850000 réis, que alguém, ou ela, pagou.

Finalmente, os velhos, os escravos com mais de 40 anos, quase todos africanos. Estavam alquebrados pelo tempo, como se diz. Embora, no caso dos escravos, isso não diga muita coisa. Para Teresa Angola, por exemplo, a idade avançada chegara aos 40 anos. A verdade é que o tempo corria mais para o escravo. Geralmente as cartas fazem alusão aos bons serviços prestados, à fidelidade e à boa conduta do cativo. Um certo Joaquim Correia Rangel foi sucinto: Joaquim Congo, de 46 anos, era um "bom escravo" (o bom Joaquim, aliás, ainda devia a ele 50000 réis, os quais pagaria em seis prestações mensais). Os bons serviços se estendiam há muito tempo, quando não pela vida inteira. $\mathrm{O}$ crioulo Vitório, de 59 anos, era dos que prestara bons serviços desde pequeno, era cria de um convento. Talvez por isso os padres acharam que ele merecia poder comprar a própria alforria por 200000 réis.

Das cartas constam muitas anotações como estas: atendendo a sua avançada idade, pela idade que tem, pela idade avançada. Haviam sido amas de leite do senhor, ajudado a criar os filhos dele e até os netos, como a escrava Felícia, de 60 anos, alforriada gratuitamente em 1845. Eram pessoas bem envelhecidas. As fontes descrevem escravos doentes, quebrados das virilhas, com feridas. Ou são lacônicas, como a do crioulo Joaquim, nascido em Minas Gerais: "escravo velho e doente". Joaquim tinha 48 
anos. Mas era por "caridade", como está escrito na carta da "velha" Felizarda crioula, de 1848, que os donos se desfaziam de seus escravos.

A maior parte destas cartas não estabelece condições, o que não espanta. Ainda assim, havia os que continuavam obrigados a servir $-15 \%$ do total dos escravos mais velhos, de mais de 40 anos. Estavam na mesma situação de uma escrava de cor parda, chamada Polucena, de mais de 60 anos, que recebeu carta com a condição acompanhar a senhora enquanto esta quisesse (ver tabela 3).

Há ainda um conjunto de cartas bastante reveladoras. Avós, irmãos, padrinhos, madrinhas, maridos, noivos, tios, tias, filhos, pais e mães, sobretudo mães, pagavam por cartas de alforria para seus parentes. Chama a atenção os meios pelos quais concluíram os seus fins.

O "preto forro" Antônio Leite soube como obter recursos para libertar o filho. Entre 1836 e 1838, desfez-se de dois escravos (José Mina Nagô, de quem recebeu a quantia de 450000 réis, e Mariana Mina, de quem recebeu outros 400000 réis) e comprou Izaías crioulo, escravo de um certo João Pinheiro de Campos. Na carta de alforria Antônio explica que agora podia reconhecê-lo como filho. Outro "preto forro", José Ribeiro, quem sabe se casado na igreja com Miquelina Cabinda, era pai de Jesuína "crioulinha", de menos de um ano de idade. Trocou a carta de alforria da filha por outra "crioulinha", de nome desconhecido. O irmão da mulata Belmira, Inácio, em 1849, procedeu do mesmo modo: deu ao senhor dela a escrava Felícia Benguela, em troca da carta da irmã. Já o "preto livre" Jacinto Diogo Therton, em 1847, pagou 800000 réis por Maria Joana, de nação Rebolo, à senhora dela, Rita Francisca da Costa, uma africana de Benguela, pessoa livre.

Mas interessante mesmo foi caso de Mariana crioula, que, em 1850, tirou a sorte grande. No dia de festa de Nossa Senhora do Rosário e São Benedito, houve um sorteio entre os membros da Irmandade de mesmo nome. O prêmio era uma carta de alforria, e Mariana ganhou.

Diante do número de africanos que o tráfico transatlântico trouxe para o Brasil (cerca de 5000000 -soma escandalosa, se comparada aos aproximados 400000 africanos embarcados para os Estados Unidos), ${ }^{13}$ a obtenção de uma carta de alforria devia parecer como ser contemplado com a sorte grande -coisa de São Benedito, um milagre. Mas o importante é que eram recorrentes o suficiente para influir decisivamente nos costumes da época, em todos os quadrantes da vida social, na economia, na política, na cultura.

A bem da verdade, sem negar o poder de síntese da carta da crioula Mariana, no revelar a quimera, as cartas de alforria, às vezes, são descon-

${ }^{13}$ Eltis, Transatlantic, 1998. 


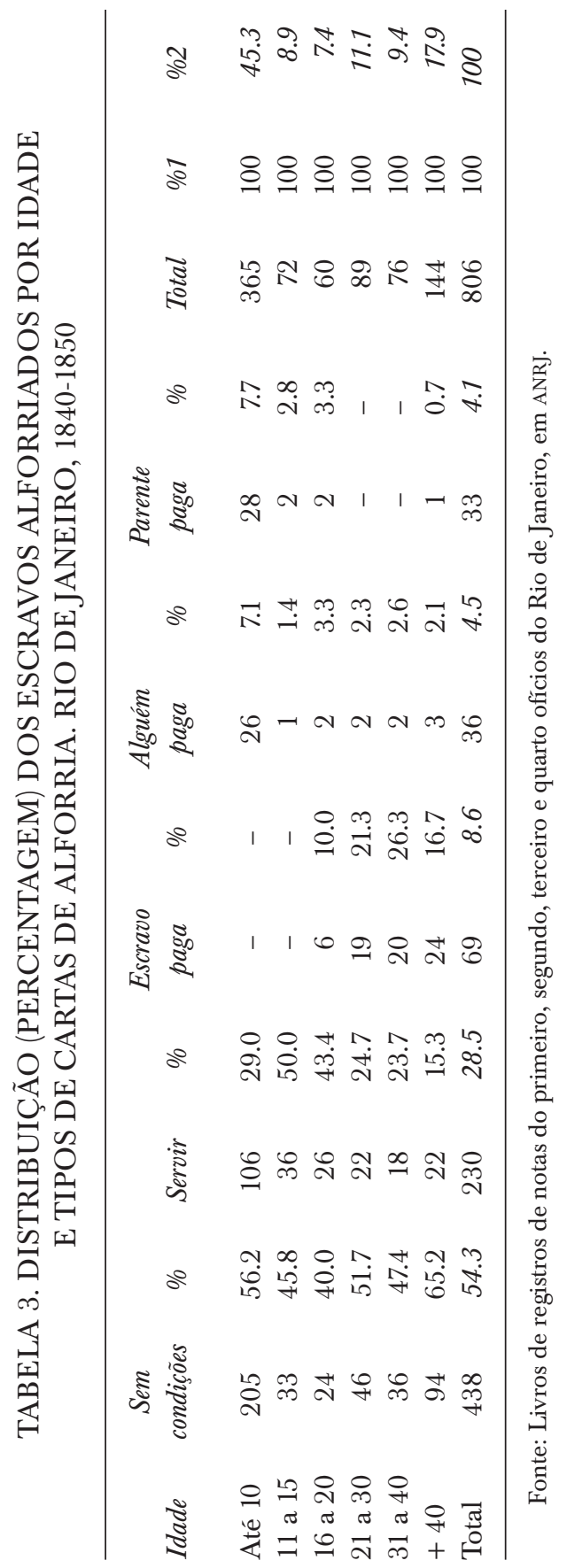


certantes. Os estudos sobre alforrias enfatizam o caráter dócil do escravo libertado e as cartas do Rio de Janeiro, monocórdicas em louvor dos bons serviços, da humildade e do bom comportamento, não os desmentem. Mas há entre elas casos que se desviam do roteiro. Por exemplo. Não foi por caridade que Antônio José Vilas Boas Sampaio passou carta de alforria gratuita para a crioula Juliana, filha de Izaías e Luiza, ambos de nação. Foi com o propósito de se livrar dela, sabe-se lá porque. A condição era que ela fosse residir a mais de uma légua da casa dele, "por causa dos seus defeitos". Outro exemplo é o de Lourenço de nação, de mais de 60 anos, por cuja carta, ele, ou alguém, pagou 250000 réis. Estava fugido desde o dia de cinzas (não é possível precisar o período) e se quisesse desfrutar da nova condição, de liberto, devia retornar e pagar ao amo os jornais referentes aos dias em que esteve fugido.

Ambos os casos revelam certa banalização da alforria na sociedade brasileira. Pois se chegava até escravos de muitos "defeitos", ou fujões...

O LIVRO DE BATISMO DAS PESSOAS LIVRES

DA Freguesia de INHaÚma, 1807-1841

A bordo do H. M. S. Malabar, inerte com seus 74 canhões na baía da Guanabara, o reverendo Pascoe Grenfell Hill enumerava o que mais vivamente o impressionava no Rio de Janeiro de 1842: "O intenso burburinho no cais, de barcos despejando passageiros ou suprindo-se; o mercado, ainda mais agitado e abarrotado, com sua profusão tropical de frutas e legumes. [Mas,] acima de tudo, as diferentes tribos da raça humana, de toda as cores e feições, que se apinham." ${ }^{14}$

O sentido do arremate se esclarece ao sabermos ter sido marcadamente negra a população descortinada pelos olhos do inglês. Também pudera: mais de 700000 cabindas, rebolos, monjolos, minas, cassanges, quiloas, moçambiques e demais haviam desembarcado na Corte ao longo dos 50 anos anteriores. Embora o tráfico quase cessasse no início dos anos 30, o contrabando logo tornou-se tão comum a ponto de, nos anos 40, as importações alcançaram patamares iguais ou superiores aos de antes. Enquanto o reverendo Hill escrevia, talvez fossem escravos dois entre cada três habitantes da Corte.$^{15}$ Logo, é possível que as cores e feições de seu texto se referissem sobretudo aos cativos -por exemplo, à população africana

${ }^{14}$ Hill, Fifty, 1993, p. 2.

${ }^{15}$ Ver Karasch, Slave, 1987, p. 61; Bethell, Abolição, 1976, pp. 366-376; Eltis, "Nineteenth-century", 1987, e Florentino, Costas, 1997, p. 51. 
(majoritária) e afro-descendente escravizada-, mas também aos chamados "homens livres de cor".

A presença da população livre de origem africana, negra ou mulata, está muito bem documentada nos livros da Igreja católica. No livro de batismos da Freguesia de Inhaúma, Rio de Janeiro, da primeira metade do século XIX, por exemplo. ${ }^{16}$

O pároco de Inhaúma mostrava-se mais cioso do que a maioria de seus pares e permitia-se registrar o nome dos pais amancebados -e em pecado, pois- quando eles compareciam à igreja para reconhecer seus filhos. Daí podermos hoje conhecer a família de Joaquim José. A "pardinha" Lucinda foi batizada em abril de 1830, na sua presença e na da mãe, a liberta Romana Bernardina da Conceição. Trata-se de uma família constituída fora do domínio da Igreja católica. A despeito de ser solteiro, Joaquim, "preto", fez questão de reconhecer e batizar a menina, tal como fizera dois anos antes com Leonidia, também filha sua com Romana. O pesquisador de hoje poderia concluir ter a mancebia contribuído muito menos para a ilegitimidade infantil do que os inúmeros pais cujos parceiros estavam efetivamente ausentes das fontes (ver tabela 4). É possível que semelhante conclusão se aplique a inúmeras regiões brasileiras. Mas ao menos para o caso de Inhaúma, contentar-se com ela, pode, como se verá, elidir faces fundamentais da sociedade escravista em questão.

Apesar do invulgar procedimento do pároco, as crianças de Inhaúma apresentavam índices de legitimidade semelhantes aos de muitas outras partes do Brasil. Como mostra a tabela 4, sete a cada dez crianças haviam sido geradas no seio de uniões que, juntando brasileiros entre si, estes com estrangeiros, negros com brancos, e mesmo escravos com mulheres forras, tinham em comum a benção da Igreja católica. É um perfil de legitimidade bastante baixo, quando comparado ao das populações livres do Ocidente. Embora não seja possível mensurar com exatidão a envergadura da ilegitimidade colonial, é dado como certo pelos especialistas a sua significativa recorrência entre os homens livres. ${ }^{17} \mathrm{Na}$ paróquia de Jacarepaguá, Rio de Janeiro, na segunda metade do século XVIII cerca de 17\% dos nascimentos eram de crianças ilegítimas (e quase a metade das mães eram ex-escravas). ${ }^{18}$ Os índices de ilegitimidade eram mais altos ainda nas Minas Gerais, à mesma época. Na Vila Rica de todas as conspirações, por

\footnotetext{
${ }^{16}$ Trata-se de um conjunto de 863 registros. Retirou-se do conjunto dos registros os batismos de escravos e de alforriados de pia, pois em geral tais registros estão adjudicados a livros próprios de batismos de escravos. Subtraiu-se também os registros (poucos) de batismos de adultos -eram poucos e podiam distorcer os padrões que se buscava, por exemplo no que tange às taxas de masculinidade da população de batizandos.

${ }^{17}$ Ver, por exemplo, Silva, Sistema, 1984, e Vainfas, Trópico, 1988.

${ }^{18}$ Venâncio, "Limites", 1986.
} 


\section{TABELA 4. DISTRIBUIÇÃO (\%) DOS BATIZANDOS \\ (POR SEXO E GRAU DE LEGITIMIDADE)}

E DE SEUS PAIS. INHAÚMA, RIO DE JANEIRO, 1807-1841

$\begin{array}{lcccc}\begin{array}{l}\text { Legitimidade dos batizandos } \\ \text { Sexo }\end{array} & \text { Crianças } & \text { Legítimos } & \text { Ilegítimos consensuais } & \\ & & & & \text { Ilegítimos }^{a} \\ \text { Masculino } & 421 & 69.6 & 7.6 & \\ \text { Feminino } & 439 & 70.8 & 5.2 & 22.8 \\ \text { Indeterminado }^{\mathrm{b}} & 3 & 100 & - & - \\ \text { Total } & 863 & 70.3 & 6.4 & 23.9\end{array}$

Estado matrimonial dos pais

Pais

Porcentagem

Mães

Porcentagem

Casados $^{\mathrm{c}}$

286

90.8

286

59.9

Permanentemente

amancebados

25

7.9

25

Permanentemente

solteiros

4

1.3

167

478

Total

315

100

100

a Trata-se de filhos de uniões consensuais cujos pais podiam ou não se casar em algum momento de sua união.

${ }^{\mathrm{b}}$ Trata-se de três crianças cujo nome (e, portanto, o sexo) não pode ser determinado.

${ }^{c}$ Inclui os pais e mães de filhos ilegítimos que depois se casaram.

Fonte: Livro de batismos de livres de Inhaúma, 1807-1841, Arquivo da Cúria Metropolitana do Rio de Janeiro (em diante ACMRJ).

exemplo, dois entre cada três livres eram ilegítimos. ${ }^{19}$ Sabe-se também, através das Devassas eclesiásticas realizadas em 1813, em doze freguesias do sul da Bahia, que as acusações referentes aos desvios na vida familiar representavam $2 / 3$ do total de 596 denúncias investigadas. Mais da metade das acusações circunscritas a este tópico referiam-se a situações de concubinato envolvendo pessoas de todos os estatutos jurídicos. ${ }^{20}$

Vários fatores tornavam altas as taxas globais de ilegitimidade colonial. Alguns autores percebem no problema o lugar particular ocupado pela população pobre no Brasil, à margem de bens e ofícios, andarilhos de um mundo instável e precário. ${ }^{21}$ Outros alertam para a escassez de padres

${ }^{19}$ Costa, Vila, 1979, p. 227.

${ }^{20}$ Ver Mott, Escravidão, 1988, pp. 52 e ss.

${ }^{21}$ Ver Vainfas, Trópico, 1988, pp. 86-87. 
e para os elevados custos do matrimônio, que tornavam este tipo de sacramento acessível apenas aos estratos mais bem aquinhoados da colônia. ${ }^{22}$ Em definitivo, porém, havia a singular dinâmica da escravidão, que estava sempre a incorporar ao mundo dos livres pessoas há pouco tempo apresentadas a Jesus, por exemplo, africanos.

Outro aspecto importante desvelado pela tabela 4 : enquanto $90 \%$ dos pais eram casados pela Igreja católica, apenas seis entre cada dez mães encontravam-se nesta situação -e para $1 / 3$ delas os possíveis parceiros eram totalmente ausentes das fontes. Ora, uma vez tomada a decisão de batizar o filho bastardo, a ida da mãe à igreja era compulsória, ao passo que para seu parceiro, quando existente, tratava-se de uma opção. Logo, a própria natureza da fonte ajuda a entender a discrepância observada quanto ao estado matrimonial de homens e mulheres, já que implica na sub-enumeração dos primeiros.

A análise da condição jurídica de pais e mães revela que as mulheres alforriadas correspondiam a 30\% de todas as mulheres que levaram filhos à pia batismal, e que 10\% dos pais também pertenciam à mesma categoria (ver tabela 5). Eis uma forte indicação da alta presença de ex-escravos na população livre de Inhaúma. A fonte também indica que estas forras contribuíam para a ilegitimidade de forma bastante diferenciada das mães livres.

Apenas $1 / 5$ das mães cuja condição jurídica era livre, era também mãe solteira, como Luiza Angélica de Jesus Tavares, que batizou dois filhos (Amélia e Ignácio), na década de 1830. O mais recorrente eram as uniões abençoadas pela sanção eclesiástica. O perfil das forras era, ao contrário, radicalmente distinto: $2 / 3$ das mães libertas eram solteiras, sem parceiro declarado e anotado pelos padres.

Existia uma forte endogamia segundo o estatuto jurídico das pessoas, especialmente quando se tratava de indivíduos que haviam nascido livres $-90 \%$ dos casos, sobretudo de mulheres. Quanto aos forros, cerca de $2 / 3$ dos casamentos e relações consensuais uniam homens e mulheres libertos. $\mathrm{O}$ outro terço era de mulheres desta condição que se casavam com homens livres, mas, às vezes, também com escravos. Não há sequer um caso de homem forro casado com mulher livre. É possível que essas mulheres forras tenham contribuído mais ao processo de miscigenação do que a mulher escravizada e, certamente, de modo intrinsecamente distinto. Pois não é implausível que a violência, derivada da própria subordinação jurídica, assumisse no intercurso entre uma escrava e o seu senhor um peso maior do que o porventura existente na relação entre uma mulher forra e um homem livre (ver tabela 6).

${ }^{22}$ Ver Boxer, Idade, 2000, p. 191, e Silva, Sistema, 1984, p. 55. 
TABELA 5. DISTRIBUIÇÃO (PERCENTAGEM) DOS PAIS, DE ACORDO À CONDIÇÃO JURÍDICA. INHAÚMA, RIO DE JANEIRO, 1807-1841

\begin{tabular}{lcccccccc}
\hline & Escravos & $\%$ & Forros & $\%$ & Livres & $\%$ & Total & $\%$ \\
& & & & & & & & \\
Pais & 2 & 0.7 & 30 & 10.3 & 258 & 89.0 & 290 & 100 \\
Mães & - & - & 135 & 29.8 & 318 & 70.2 & 453 & 100 \\
Total & 2 & 0.3 & 165 & 22.2 & 576 & 77.5 & 743 & 100 \\
\hline
\end{tabular}

Fonte: Livro de batismos de livres de Inhaúma, 1807-1841, em ACMrJ.

TABELA 6. DISTRIBUIÇÃO (\%) DOS PAIS CASADOS E AMANCEBADOS, DE ACORDO À CONDIÇÃOJURÍDICA. INHAÚMA, RIO DE JANEIRO, 1807-1841

\section{Casados e amancebados}

Homens

$\begin{array}{lccclccr} & \text { Escravas } & \text { Forras } & \text { Livres } & & \text { Escravos } & \text { Forros } & \text { Livres } \\ \text { Escravos } & - & 100 & - & \text { Escravas } & - & - & - \\ \text { Forros } & - & 100 & - & \text { Forras } & 4 & 69 & 27 \\ \text { Livres } & - & 5 & 95 & \text { Livres } & - & - & 100\end{array}$

Casados

Homens

$\begin{array}{lccclccr} & \text { Escravas } & \text { Forras } & \text { Livres } & & \text { Escravos } & \text { Forros } & \text { Livres } \\ \text { Escravos } & - & 100 & - & \text { Escravas } & - & - & - \\ \text { Forros } & - & 100 & - & \text { Forras } & 11 & 81 & 13 \\ \text { Livres } & - & 2 & 98 & \text { Livres } & - & - & 100\end{array}$

Amancebados

Homens

\begin{tabular}{lccclccc} 
& Escravas & Forras & Livres & & Escravos & Forros & Livres \\
Escravos & - & - & - & Escravas & - & - & - \\
Forros & - & 100 & - & Forras & - & 33 & 67 \\
Livres & - & 38 & 62 & Livres & - & - & 100 \\
\hline
\end{tabular}

Fonte: Livro de batismos de livres de Inhaúma, 1807-1841, em ACMRJ. 
A mulher forra era o exemplo mais recorrente de mobilidade social e de miscigenação. Fazia circular valores, símbolos e práticas próprias da casa grande e da senzala, amalgamando-os. Era a própria herança escrava e africana, lançada ao mundo dos homens livres pelas senzalas (ou nelas capturadas, a bem dizer). Os vínculos da forra com a África, e com a escravidão, haviam de permanecer, pois certamente possuía parentes escravos -o tio, a mãe, o pai, o filho, o marido (quantas dessas mães forras solteiras não eram exemplos de uniões consensuais estabelecidas com escravos, quando ainda eram cativas?). E porque, afinal, nascera escrava, filha de uma família escrava. A mulher liberta trazia da escravidão para o meio dos livres também a mancebia, e se fazia acompanhar, na fonte, de outros escravos: a maioria das mães permanentemente solteiras não apenas eram forras, como também tinham, por padrinhos e madrinhas de seus filhos, majoritariamente, ex-escravos e cativos (ver tabela 7).

$\mathrm{Na}$ análise do livro, até agora, não levamos em consideração um conjunto de 45 registros, relativos a mães escravas que foram anotadas no livro porque seus filhos haviam obtido cartas de alforria ao nascer. Elas eram mães solteiras na proporção de $9 / 10$, enquanto as solteiras entre as forras eram ${ }^{2} / 3$ e, entre as livres, $1 / 5$. É nítida a relação entre a situação jurídica e o estado matrimonial das mães. É possível, pois, a pergunta: quantas destas mulheres livres, mães solteiras, não eram filhas ou netas de escravos? Jamais saberemos.

O livro de batismos da rural Inhaúma também documenta uma razoável população européia, algo em torno de $15 \%$ dos pais livres, praticamente todos nascidos em Portugal. Diante da fluidez assumida pelas categorias relativas à cor em nossa história, trata-se do único grupo formado sem sombra de dúvida por "brancos". Acompanhá-lo pode oferecer algumas importantes informações acerca da dinâmica que nos fez tão fortemente miscigenados.

Os europeus de Inhaúma provinham sobretudo do norte de Portugal e das ilhas do Atlântico, do Douro e do Minho, dos Açores e da Madeira. A migração estava marcada, por um notável predomínio masculino: nada menos do que nove entre cada dez anotados no livro eram homens. Tratava-se de um padrão nada peculiar -fora assim, desde o início da colonização. ${ }^{23}$

As mulheres portuguesas não casavam com homens brasileiros. Em termos gerais, ou bem elas desembarcavam no Brasil com os seus cônjuges (o que parece ter sido o caso sobretudo daquelas provenientes das ilhas do Atlântico e do Algarve), ou, quando vinham solteiras, uniam-se quase que exclusivamente a seus próprios compatriotas. O comportamento ra-

\footnotetext{
${ }^{23}$ Brettell, Homens, 1991, pp. 90 e ss.
} 
TABELA 7. DISTRIBUIÇÃO (\%) DOS PADRINHOS E MADRINHAS, DE ACORDO À CONDIÇÃO JURÍDICA. INHAÚMA, RIO DE JANEIRO, 1807-1841

\begin{tabular}{|c|c|c|c|c|c|c|}
\hline & \multicolumn{3}{|c|}{$\begin{array}{c}\text { Condição jurídica } \\
\text { dos padrinhos }\end{array}$} & \multicolumn{3}{|c|}{$\begin{array}{c}\text { Condição jurídica } \\
\text { das madrinhas }\end{array}$} \\
\hline & Escravos & Forros & Livres & Escravas & Forras & Livres \\
\hline Filhos de pais casados ${ }^{\mathrm{a}}$ & 27.3 & 36.2 & 73.6 & 50.0 & 28.0 & 80.9 \\
\hline $\begin{array}{l}\text { Filhos de pais } \\
\text { permanentemente } \\
\text { amancebados }\end{array}$ & 18.2 & 10.6 & 5.2 & - & 16.0 & 2.8 \\
\hline $\begin{array}{l}\text { Filhos de pais } \\
\text { permanentemente } \\
\text { solteiros }\end{array}$ & 54.5 & 53.2 & 21.2 & 50.0 & 56.0 & 16.3 \\
\hline Total & 100 & 100 & 100 & 100 & 100 & 100 \\
\hline
\end{tabular}

${ }^{\text {a } I n c l u i ~ o s ~ p a i s ~ e ~ m a ̃ e s ~ d e ~ f i l h o s ~ i l e g i ́ t i m o s ~ q u e ~ d e p o i s ~ s e ~ c a s a r a m . ~}$

Fonte: Livro de batismos de livres de Inhaúma, 1807-1841, em ACMRJ.

dicalmente endogâmico as transformava em instrumentos de manutenção e afirmação de uma identidade o mais lusitana possível nos trópicos. Esta podia expressar-se tanto em esferas por muitos sempre referidas -como a culinária à base de sopas e de "enchidos", por exemplo-, quanto principalmente no fervor com que assumiam as práticas católicas. Eis aqui um importante elemento explicativo de um traço que distinguia fortemente os rebentos dos portugueses de Inhaúma: os seus altos graus de legitimidade. Em um perfil bastante distante do prevalecente entre outras mulheres, não havia mães solteiras entre as portuguesas da freguesia fluminense. Sequer as havia amancebadas, pois, de acordo aos registros de batismos, nenhuma mãe lusa prescindia do sancionamento da Igreja católica para a consecução de seu matrimônio (ver tabela 8).

Quanto aos homens portugueses, grande parte se casava com mulheres brasileiras de primeira geração, isto é, cujos pais haviam nascido em Portugal, sobretudo no norte do país. Isto significa que havia uma certa ordenação na busca por mulheres por parte dos patrícios d'além mar. Eles eram seletivos, quando o assunto era casamento: buscavam portuguesas até onde estas fossem disponíveis, partiam para as brasileiras brancas descendentes de imigrantes lusos recentes, e, por fim, para as brasileiras brancas de longínqua ascendência lusitana. Mas o homem português casava com mulheres portuguesas e brasileiras, livres e brancas, mas também 
TABELA 8. DISTRIBUIÇÃO (\%) DOS BATIZANDOS E DE SEUS PAIS PORTUGUESES. INHAÚMA, RIO DE JANEIRO, 1807-1841

Legitimidade dos batizandos

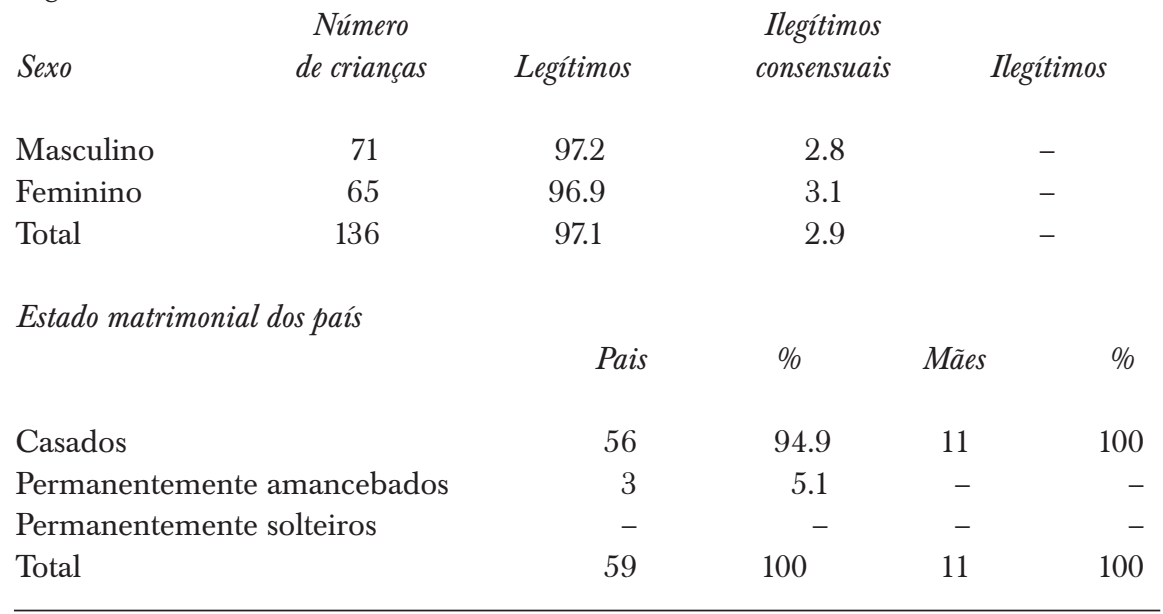

Fonte: Livro de batismos de livres de Inhaúma, 1807-1841, em ACMRJ.

casava com mulheres alforriadas, pardas e negras. Não se furtava a se relacionar com mulheres de cor, com escravas -cujas provas, os rebentos pardos e mulatos, podem ser encontradas a rodo nos livros de batismos de escravos e nas alforrias-, mas sobretudo com algumas mulheres que apenas haviam saído do cativeiro.

Na verdade, não era tão incomum casos como o de Domingos da Costa, natural de Braga, casado com a parda forra Joaquina Roza Viana (de Inhaúma), que por duas vezes, em 1822 e em 1825, levou à pia batismal os filhos de ambos -um dos quais, a pequena Guilhermina, tinha Nossa Senhora por madrinha. Ou ainda o de Manuel Nunes Cordeiro, da Ilha do Faial, amancebado com a parda forra Maria Rosa, que em 1817 batizou Nicalio, tendo por padrinho Bonifácio Jesus e por madrinha Nossa Senhora. No total, ainda de acordo aos registros, quase 10\% dos pais portugueses de Inhaúma casavam ou, minoritariamente, simplesmente viviam com mulheres pretas ou pardas, a maioria das quais forras. 


\section{CONClusão}

Homem de uma só idéia, como se definiu certa vez numa carta ao Barão de Penedo, Joaquim Nabuco redigiu, aos 34 anos, uma pequena obra-prima do pensamento social brasileiro, cujo título era também o nome de sua obsessão: $O$ Abolicionismo. ${ }^{24}$ Possivelmente, foi a mais arguta das análise sobre a escravidão que o século XIX produziu. Nele, Nabuco escreveu que a escravidão não chegava a "azedar" a alma do escravo contra o senhor, "nem criou entre as duas raças o ódio recíproco que existe naturalmente entre opressores e oprimidos... a cor no Brasil não é, como nos Estados Unidos, um preconceito social contra cuja obstinação pouco pode o caráter, o talento e o mérito de quem incorre nele". ${ }^{25}$

Opiniões semelhantes eram comuns entre todos os que achavam que a escravidão brasileira era peculiarmente branda, quando comparada a outras sociedades escravistas americanas. (Nestas, por sua vez, também havia os que se achavam mais piedosos. Em 1818, por exemplo, plantadores e comerciantes cubanos, indignados com os termos de um tratado sobre o tráfico transatlântico acertado entre Inglaterra e Espanha, escreveram que era preferível trazer os africanos para Cuba que para o Brasil, pois os espanhóis os tratavam melhor). ${ }^{26}$ Mas Joaquim Nabuco possuía outros motivos, que não a suposta superioridade dos modos lusitanos, para escrever o que escreveu.

O primeiro era de caráter demográfico. Se dependesse apenas da população do reino não havia como viabilizar a colonização de tão vasto território. E, por isso, mandaram vir africanos em enorme quantidade. Para usar a imagem do próprio Nabuco, a África estendeu-se então das margens do Congo e do Zambezi às do São Francisco e do Paraíba do Sul. ${ }^{27}$ A miscigenação e a relativa facilidade com que se transitava de escravo a senhor, sem que a cor fosse obstáculo, eram os outros motivos. A escravidão brasileira não se tornara um monopólio dos brancos: "a escravidão entre nós manteve-se aberta e estendeu os seus privilégios a todos indistintamente: brancos ou pretos, ingênuos ou libertos, escravos mesmos, estrangeiros ou nacionais, ricos ou pobres". ${ }^{28} \mathrm{~A}$ escravidão retirava forças de um profundo enraizamento social.

Em Memória póstumas de Brás Cubas, Machado de Assis mostrou até onde podia ir o processo de integração do negro e ex-escravo na sociedade brasileira do século XIX. Prudêncio sofrera o diabo, quando criança, nas mãos do iô-iô Brás Cubas. Foi alforriado após o falecimento do pai deste.

${ }^{24}$ Nabuco, Abolicionismo, 1988.

${ }^{25}$ Ibid., p. 38.

${ }^{26}$ Gorender, Escravismo, 1980, p. 349.

${ }^{27}$ Nabuco, Abolicionismo, 1988, p. 106.

${ }^{28}$ Ibid., p. 126. 
Anos depois, seu antigo sinhozinho o encontrou no Valongo, a bater num seu escravo, sob o silêncio e a complacência de um pequeno ajuntamento de homens livres. "Cala a boca, besta", gritava Prudêncio; "Meu Senhor", gemia o escravo. Após pedir que parasse com aquilo, Brás Cubas concluiu consigo mesmo: "comprou um escravo, e ia-lhe pagando, com alto juro, as quantias que de mim recebera. Vejam as subtilezas do maroto!" ${ }^{29}$ Vê-se bem as sutilezas da escravidão que Machado conheceu.

Antônio Leite, "preto" liberto, para comprar o filho, vendeu dois escravos que possuía. José Ribeiro, outro preto liberto, trocou a filha por outra "crioulinha”. Inácio trocou a irmã por uma africana. O "preto livre" Jacinto Diogo Therton comprou a liberdade de Maria Rebolo da senhora dela, uma africana de Benguela, pessoa livre. As cartas de alforria do Rio de Janeiro (e também o livro de batismo de Inhaúma) comprovam que Nabuco estava certo em creditar à recorrência com que ex-escravos e descendentes, negros ou mestiços, tornavam-se senhores de escravos, a singularidade brasileira. Por isso não chegava a azedar a alma do escravo, nem instaurava o ódio entre raças que, afinal, se misturavam. Como na química, a sociedade era "um composto, do qual a escravidão representa a afinidade causal" ${ }^{30}$ Às vésperas da abolição, na opinião de Joaquim Nabuco, a parte da população que descendia de escravos era tão numerosa como a que descendia exclusivamente dos senhores: "a raça negra nos deu um povo", escreveu. ${ }^{31}$

Nabuco chamou a atenção para os elementos básicos da singularidade brasileira. $\mathrm{O}$ contínuo e numeroso tráfico transatlântico permitia alforriar um escravo aqui e comprar um africano acolá. Foi assim até 1850, variando, é claro, segundo as conjunturas econômicas e o ritmo do tráfico. Por outro lado, num contexto de acentuada miscigenação racial, mulatos e negros tinham acesso ao mercado de escravos, o que conferia à ordem escravocrata um consenso para além das fronteiras da cor.

\section{FONTES CONSULTADAS}

\section{Arquivos}

ANRJ Arquivo Nacional, Rio de Janeiro, Brasil.

ACMRJ Arquivo da Cúria Metropolitana, Rio de Janeiro, Brasil.

\footnotetext{
${ }^{29}$ Assis, Memórias, 1997, pp. 109-110.

${ }^{30}$ Nabuco, Abolicionismo, 1988, p. 127.

${ }^{31}$ Ibid., p. 37.
} 


\section{Bibliografia}

Assis, Machado De, Memórias póstumas de Brás Cubas, São Paulo, Globo, 1997.

BARICKMAN, BERT, "As cores do escravismo: escravistas pretos, pardos e cabras no Recôncavo baiano, 1835", População e Família, num. 2, 1999, pp. 7-59.

Bethell, Leslie, A abolição do tráfico de escravos no Brasil, São Paulo, Expressão e Cultura/Universidade de São Paulo, 1976.

Boxer, Charles R., A idade de ouro do Brasil (dores de crescimento de uma sociedade colonial), Rio de Janeiro, Nova Fronteira, 2000.

Brettell, Caroline B., Homens que partem, mulheres que esperam, Lisboa, Dom Quixote, 1991.

Caminha, Pero Vaz de, "Carta de Pero Vaz de Caminha" in Darcy Ribeiro et al., $A$ fundação do Brasil, Petrópolis, Editora Vozes, 1992.

Costa, Iraci del Nero DA, Vila Rica: população (1729-1826), São Paulo, Fundação Instituto de Pesquisas Econômicas/Universidade de São Paulo, 1979. Arraia-miúda, São Paulo, MGSP Editores, 1992.

Eltis, DaVID, "The Nineteenth-Century Transatlantic Slave Trade: An Annual Time Series of Imports into the Americas Broken Down by Region", Hispanic American Historical Review, Duke University, vol. 67, num. 1, 1987, pp. 109-138. et al., The Transatlantic Slave Trade, database, Wilson Library-Emory University, 1998, <http://wilson.library.emory.edu:9090>. [Consultado: 15 de janeiro de 2010.]

FARIA, SheIla DE C., A colônia em movimento, Rio de Janeiro, Nova Fronteira, 1998.

Florentino, MANOlo, Em costas negras (uma história do tráfico de escravos entre a África e o Rio de Janeiro, séculos 18 e 19), São Paulo, Companhia das Letras, 1997. e José R. Góes, "Crianças escravas, crianças dos escravos" in MARY DEL PRIORE (org.), História das crianças no Brasil, São Paulo, Contexto, 1999, pp. 177-191. Gorender, Jacob, O escravismo colonial, São Paulo, Ática, 1980.

Graham, Maria, Diário de uma viagem ao Brasil, Belo Horizonte, Itatiaia São Paulo/ Universidade de São Paulo, 1990.

Hill, Pascoe G., Fifty Days on Board a Slave-Vessel, Baltimore, Black Classic Press, 1993. Karasch, Mary C., Slave Life in Rio de Janeiro, 1808-1850, Princeton, Princeton University Press, 1987.

Klein, Herbert S., "A experiência afro-americana numa perspectiva comparativa. A questão atualdo debate sobre a escravidão nas Américas”, Afro-Asia, num. 45, 2012, Salvador, Bahia, pp. 95-122.

Koster, Henry, Viagens ao Nordeste do Brasil, Recife, Secretaria de Educação e CulturaGoverno do Estado de Pernambuco, 1978.

Luna, Francisco Vidal e Iraci del Nero da Costa, Minas colonial: economia e sociedade, São Paulo, Fundação Instituto de Pesquisas Econômicas/Pioneira, 1982.

Mattoso, Kátia M. DE Queirós, “A carta de alforria como fonte complementar para o estudo da rentabilidade da mão de obra escrava urbana (1819-1850)" em CARlos Manoel Peláez et al. (orgs.), A moderna história econômica, Rio de Janeiro, 
Associação dos Pesquisadores e Estudantes Brasileiros na Catalunha, 1976, pp. 149-164.

Motт, LuIZ, Escravidão, homossexualidade e demonologia, São Paulo, Ícone, 1988.

Nabuco, Joaquim, O abolicionismo, Petrópolis, Vozes, 1988.

Paiva, Clotilde, "População nas Minas Gerais do século XIX”, tese de doutoramento, Brasil, Universidade de São Paulo, 1996.

Recenseamento Geral do Brasil em 1872, Rio de Janeiro, Typ. G. Leuzinger, 1874?, em Coleção digital do Instituto Brasileiro de Geografia e Estatística, <http://biblioteca. ibge.gov.br/d_detalhes.php?id=225477>. [Consulta: 15 de janeiro de 2010.]

Silva, Maria B. N. DA, Sistema de casamento no Brasil colonial, São Paulo, Universidade de São Paulo, 1984.

Tannembaum, Frank, El negro en las Américas (esclavo y ciudadano), Buenos Aires, Paidós, 1968.

Vainfas, Ronaldo, Trópico dos pecados, Rio de Janeiro, Campus, 1988.

VEnÂnCIO, RENATO P., "Nos limites da sagrada família: ilegitimidade e casamento no Brasil colonial" in Ronaldo VAinfas (org.), História da sexualidade no Brasil, Rio de Janeiro, Graal, 1986, pp. 107-123. 